\title{
Cytochrome P450 1B1
}

National Cancer Institute

\section{Source}

National Cancer Institute. Cytochrome P450 1B1. NCI Thesaurus. Code C104237.

Cytochrome P450 1B1 (543 aa, $61 \mathrm{kDa}$ ) is encoded by the human CYP1B1 gene. This protein plays a role in the metabolism of steroids and xenobiotics. 